\title{
Treatment of Cervical Dysplasia by Clinicians Who Perform Colpos- copy in German-speaking Countries - a Questionnaire-based Study
}

\section{Behandlung zervikaler Dysplasien durch Kolposkopiker im deutschsprachigen Raum - eine Fragebogenstudie}

(ㄷ) (1) (오우

Authors

Ziad Hilal ${ }^{1}$, Clemens B. Tempfer ${ }^{2}$, Günther A. Rezniczek ${ }^{2}$

\section{Affiliations}

1 ZYDOLAB, Institut für klinische Zytologie und Immunzytochemie, Dortmund, Germany

2 Klinik für Frauenheilkunde und Geburtshilfe, Marien Hospital Herne, Universitätsklinikum der Ruhr-Universität Bochum, Herne, Germany

Key words

CIN, colposcopy, conisation, management, screening, cervical dysplasia, cervical carcinoma

\section{Schlüsselwörter}

CIN, Kolposkopie, Konisation, Management, Screening, zervikale Dysplasie, Zervixkarzinom

received 25.9.2018

revised 1.1 .2019

accepted 3.1.2019

Bibliography

DOI https://doi.org/10.1055/a-0828-7831

Geburtsh Frauenheilk 2019; 79: 189-197 @ Georg Thieme

Verlag KG Stuttgart · New York | ISSN 0016-5751

\section{Correspondence}

Dr. med. Ziad Hilal, MIAC

ZYDOLAB - Institut für klinische Zytologie

und Immunzytochemie Dres. Hilal

Markt 10, 44137 Dortmund, Germany

z.hilal@zydolab.de

Deutsche Version unter:

https://doi.org/10.1055/a-0828-7831

\section{ABSTRACT}

Introduction In connection with the reorganisation of cervical carcinoma screening, the importance of colposcopy as an integral part of the planned series of clarification testing will greatly increase. Quality standards for performing the colposcopic examination should therefore be defined in detail. A precondition for this is surveying the current standard in clinical practice. The objective of this study was to evaluate the current practice of colposcopy and conisation in Germany by means of a questionnaire aimed at gynaecologists who perform colposcopies in order to document the actual therapeutic standard of treatment of cervical dysplasia.

Materials and Methods Gynaecologists were invited via e-mail or during events to participate in a web-based survey. The questionnaire contained 38 questions on management before, during and after the examination as well as questions on the technical implementation of colposcopy and conisation.

Results From February 2018 to April 2018, 961 e-mails were sent. A response was received in 197 cases (response rate $20.5 \%$ ). Responses were received for another 40 questionnaires during events (response rate approx. 80\%). After taking the inclusion criteria into account, 160 questionnaires were evaluated. The majority of those surveyed take an average of 2 cervical biopsies (67.3\%) and nearly all of those surveyed (94.5\%) do not use any local anaesthetic. As a standard method for removing cervical precancerous cells, most of the physicians surveyed perform a loop excision with the electrosurgical loop (91.2\%) under colposcopic visualisation (61.2\%) under general anaesthesia (92.5\%). Postoperative bleeding prophylaxis by means of tamponade is performed only in $27.6 \%$ of all cases.

Conclusion A differential colposcopy with two colposcopically targeted biopsies and treatment with the electrosurgical loop are the methods most frequently used by clinicians who perform colposcopy in Germany. A uniform procedure should be defined in detail within the scope of directives or guidelines.

\section{ZUSAMMENFASSUNG}

Einleitung Im Zusammenhang mit der Neuausrichtung des Zervixkarzinomscreenings wird die Bedeutung der Kolposkopie als integraler Bestandteil der geplanten Abklärungskaskade stark zunehmen. Qualitätsstandards für die Durchführung der kolposkopischen Untersuchung sollten daher detailliert festgelegt werden. Voraussetzung dafür ist die Erhebung des derzeitigen Standards in der klinischen Praxis. Ziel der vorlie- 
genden Studie war es, mittels eines an kolposkopisch tätige Frauenärzte gerichteten Fragebogens die gegenwärtige Praxis der Kolposkopie und Konisation in Deutschland zu evaluieren, um den faktischen Therapiestandard der Behandlung zervikaler Dysplasien zu erheben.

Material und Methodik Frauenärzte wurden per E-Mail oder bei Veranstaltungen eingeladen, an einer webbasierten Befragung teilzunehmen. Der Fragebogen beinhaltete 38 Fragen zum Management vor, während und nach der Untersuchung, sowie Fragen zur technischen Durchführung von Kolposkopie und Konisation.

Ergebnisse Im Zeitraum Februar 2018 bis April 2018 wurden 961 E-Mails zugestellt. Antwort erfolgte in 197 Fällen (Rücklaufquote 20,5\%). Die Beantwortung weiterer 40 Fragebögen wurden im Rahmen von Veranstaltungen erreicht (Rücklaufquote ca. $80 \%$ ). Nach Berücksichtigung der Einschlusskrite- rien wurden 160 Fragebögen ausgewertet. Die Mehrheit der Befragten entnimmt im Durchschnitt 2 zervikale Biopsien (67,3\%), wobei nahezu alle Befragten (94,5\%) keine örtliche Betäubung anwenden. Als Standardmethode zur Entfernung zervikaler Präkanzerosen führen die meisten Befragten die Schlingenexzision mit der Loop-Schlinge $(91,2 \%)$ unter kolposkopischer Sicht $(61,2 \%)$ in Vollnarkose $(92,5 \%)$ durch. Eine postoperative Blutungsprophylaxe mittels Tamponade wird lediglich in 27,6\% aller Fälle durchgeführt.

Fazit Eine Differenzialkolposkopie mit 2 kolposkopisch gezielten Biopsien und die Schlingenexzision mit der Loop-Schlinge sind die von Kolposkopieexperten in Deutschland am häufigsten angewandten Methoden. Eine einheitliche Vorgehensweise sollte im Rahmen von Richt- oder Leitlinien detailliert festgelegt werden.

\section{Introduction}

Cervical carcinoma is the fourth most common cancer disease in women worldwide and is also in fourth place among all cancer-related deaths [1]. In parallel with the introduction of a comprehensive screening, the incidence significantly decreased in industrialised Western nations in recent decades. However, the number of new diseases has remained static in Germany since the turn of the millennium at approx. 4500 [2]. This circumstance led to a paradigm shift in gynaecological cancer screening and the elimination of the previous opportunistic screening. Improved early detection should now enable a further reduction in the number of new cervical carcinomas within the scope of an organised screening programme which is still being established [3].

An important change in the new screening, in addition to the introduction of the co-testing with the PAP smear and human papilloma virus (HPV) test for women aged 35 and over, is also the indispensable use of differential colposcopy as an integral part of the series of clarification testing [4]. Based on the quality assurance criteria of the European Federation for Colposcopy (EFC) [5], the quality of a dysplasia facility has been documented and evaluated in German-speaking countries (Austria, Germany, Switzerland) since 2008 using a uniform certification system [6]. Other colposcopy societies additionally define standards in the practical and technical implementation of colposcopy and conisation [79]. Comparable recommendations are missing in German-speaking countries. So far, the discussions have primarily focused on the management of cervical dysplasia and the optimal clarification algorithm. In view of the significant, expected increase in the utilisation of dysplasia consultations and units in the organised screening, the focus should also turn to the optimal treatment of affected women within the scope of colposcopic clarification. However, there is a lack of in-depth investigations on this topic to date. A uniform procedure for ensuring a high level of quality and safeguarding standards is especially indispensible here, however.

In this study, gynaecologists in German-speaking countries who perform colposcopy were invited via e-mail or at events to participate in a web-based survey. The questionnaire contained questions on the management of patients before, during and after the examination as well as questions on the technical implementation of colposcopy and conisation. The objective was to evaluate the current practice in order to define a possible standard from it in the future for the treatment of patients during a consultation by a dysplasia facility.

\section{Materials and Methods}

\section{Study design and target group}

The online-based questionnaire was aimed at gynaecologists in the German-speaking countries (Germany, Austria, Switzerland) who perform colposcopies. The background is the joint certification process of a dysplasia facility in all three countries [6]. The objective of this survey was to evaluate the organisational, instrument-related and technical approach of gynaecologists within the framework of clarifying cervical dysplasia using colposcopy as well as the surgical treatment of dysplasia using conisation. The questionnaire drafted for this purpose consisted of 38 questions. The questionnaire was divided into three parts: the first part contained general questions about the person participating (sex, age, professional career) as well as questions on qualifications regarding colposcopy. The second part related to patient information, the technical execution, the documentation and the management of complications within the scope of colposcopy. The third part of the questionnaire addressed the technical execution of the conisation as well as the management of complications during and after the conisation.

A vote from the Ethics Committee of the Medical Faculty of the Ruhr University Bochum was obtained (registration number 186259 dated 20/02/2018).

\section{Data acquisition/management and statistical analyses}

REDCap (Research Electronic Data Capture) was used as a study database [10]. REDCap is a secure, web-based application which was developed specifically for data collection within the frame- 


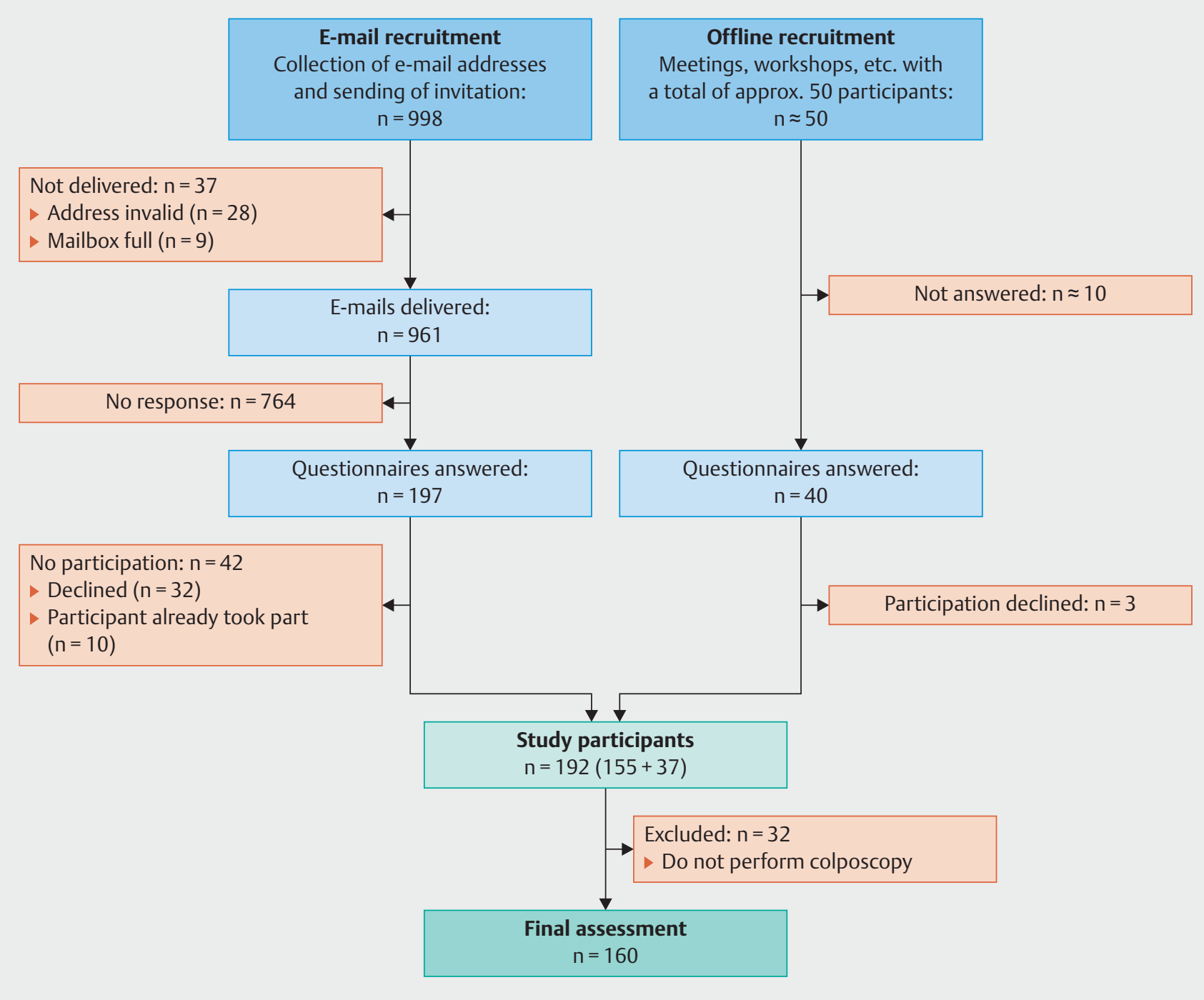

- Fig. 1 Schematic representation of the implementation of the study.

work of medical studies. Among other things, it offers the option to generate and provide online questionnaires as well as to automatically send invitations via e-mail for participation. The e-mail addresses of potential study participants came from publicly accessible websites (e.g. from medical practices or hospitals) and publicly accessible registries (e.g. dysplasia consultations in Germany on the pages of the German Society of Colposcopy and Cervical Pathology) in Germany, Switzerland and Austria.

The invitation to participate in the study contains a link to the online questionnaire. This link was specific for each participant and made it possible to track whether a particular invitation yielded a response and prevented repeated participation. If the person invited did not respond, up to two reminders were sent at 14-day intervals in each case. At the same time as the recruitment via e-mail, potential participants were informed of the study at conferences or other professional events and invited to take part. A general link to the online questionnaire (in text form or as QR code) was provided for this purpose.
The data collected were described using descriptive statistics. Any comparisons of subgroups were performed in the case of categorical variables using Fisher's exact test or $x^{2}$ test. In the case of continuous variables, comparisons were made between two groups using Student's t test (for data which followed a normal distribution) and the Mann-Whitney $U$ test (for data without a normal distribution).

\section{Results}

\section{Participant recruitment}

From February 2018 to April 2018, 998 invitations to participate in the study were sent via e-mail. A total of 37 invitations were undeliverable (invalid addresses, full inbox) and thus it is assumed that 961 were delivered to the corresponding inboxes. At the same time, an invitation to participate in the study was issued at several events with a total of about 50 participants. In 237 cases, 
- Table 1 Characteristics of the study population.

\begin{tabular}{|c|c|}
\hline Characteristic & Value \\
\hline Number of questionnaires evaluated & 160 \\
\hline Age (years) & $42(36-51)[3]$ \\
\hline Sex (female/male) & $102(64.6 \%) / 56(35.4 \%)[2]$ \\
\hline Professional activity (years) & $15(9-23)[1]$ \\
\hline Country of work as physician* & [23] \\
\hline - Germany & $115(83.9 \%)$ \\
\hline - Austria & $7(5.1 \%)$ \\
\hline - Switzerland & $15(10.9 \%)$ \\
\hline Place of work as physician* & [2] \\
\hline - practice & $59(37.3 \%)$ \\
\hline - hospital, with job title: & $110(69.6 \%)$ \\
\hline - Assistant physician & $12(10.9 \%)$ \\
\hline - Specialist & $18(16.4 \%)$ \\
\hline - Senior physician & $68(61.8 \%)$ \\
\hline - Chief physician & $9(8.2 \%)$ \\
\hline - other & $3(2.7 \%)$ \\
\hline Doctorate (Dr. med.) (yes/no) & $133(83.6 \%) / 26(16.4 \%)[1]$ \\
\hline Type of colposcopic training: & [2] \\
\hline - basic course & $30(19.0 \%)$ \\
\hline - advanced course & $10(6.3 \%)$ \\
\hline - certificate & $28(17.7 \%)$ \\
\hline $\begin{array}{l}\text { - certified dysplasia consultation/ } \\
\text { centre }\end{array}$ & $87(55.1 \%)$ \\
\hline - other & $3(1.9 \%)$ \\
\hline $\begin{array}{l}\text { Number of years performing } \\
\text { colposcopies }\end{array}$ & $8(4-15)[2]$ \\
\hline $\begin{array}{l}\text { Number of women with genital } \\
\text { dysplasia treated to date: }\end{array}$ & [4] \\
\hline - fewer than 200 & 40 (25.7\%) \\
\hline - 200 to 300 & $20(12.8 \%)$ \\
\hline - more than 300 & $96(61.5 \%)$ \\
\hline $\begin{array}{l}\text { Number of women with genital } \\
\text { dysplasia treated annually: }\end{array}$ & [3] \\
\hline - fewer than 50 & $39(24.8 \%)$ \\
\hline - 50 to 100 & $35(22.3 \%)$ \\
\hline - more than 100 & $83(52.9 \%)$ \\
\hline Performs conisations (yes/no) & $136(85.0 \%) / 24(15.0 \%)$ \\
\hline \multicolumn{2}{|c|}{$\begin{array}{l}\text { Values are the number (proportion in percent) or median (interquartile } \\
\text { range). Numbers in square brackets indicate the number of missing val- } \\
\text { ues. }{ }^{*} \text { Multiple selections possible (amounts may yield }>100 \% \text { ). }\end{array}$} \\
\hline
\end{tabular}

the potential participants responded to the invitation; this corresponds to a response rate of a total of $23.4 \%$ (20.5\% from the recruitment via e-mail, approx. $80 \%$ at the events). 35 participants (14.8\%) declined study participation and 10 participants (4.2\%) from the e-mail branch indicated that they had already participated in the study (duplicate e-mail addresses or already recruited at an event; this yields 227 individual participants), and thus 192
- Table 2 Conducting patient information.

\begin{tabular}{|c|c|}
\hline Parameter & Value \\
\hline $\begin{array}{l}\text { Detailed information on the signifi- } \\
\text { cance of genital dysplasia directly } \\
\text { before the colposcopic examination? } \\
\text { (yes/no) }\end{array}$ & $148(93.1 \%) / 11(6.9 \%)[1]$ \\
\hline \multicolumn{2}{|l|}{ If yes, then is information provided ... } \\
\hline - verbally by the physician & $146(98.6 \%)$ \\
\hline $\begin{array}{l}\text { - additionally through informational } \\
\text { brochures or information video }\end{array}$ & $52(35.1 \%)$ \\
\hline $\begin{array}{l}\text { - exclusively through an information } \\
\text { brochure }\end{array}$ & $2(1.4 \%)$ \\
\hline $\begin{array}{l}\text { Offer of informational material prior } \\
\text { to the appointment for colposcopy } \\
\text { (yes/no) }\end{array}$ & $61(38.9 \%) / 96(61.1 \%)[3]$ \\
\hline If yes, by... & [1] \\
\hline - information brochures exclusively & $38(63.3 \%)$ \\
\hline $\begin{array}{l}\text { - exclusively links to informational } \\
\text { material online }\end{array}$ & $12(20.0 \%)$ \\
\hline - brochures as well as links & $10(16.7 \%)$ \\
\hline Written consent obtained (yes/no) & $15(9.6 \%) / 142(90.4 \%)[3]$ \\
\hline $\begin{array}{l}\text { Patients receive written information } \\
\text { on steps to take after the colposcopy } \\
\text { (yes/no) }\end{array}$ & $18(11.5 \%) / 139(88.5 \%)[3]$ \\
\hline $\begin{array}{l}\text { Offer of an option for contact for } \\
\text { emergencies after the colposcopy } \\
\text { (yes/no) }\end{array}$ & $123(77.8 \%) / 35(22.2 \%)[2]$ \\
\hline $\begin{array}{l}\text { Values are a number (proportion in per } \\
\text { range). Numbers in square brackets inc } \\
\text { values. }\end{array}$ & $\begin{array}{l}\text { ) or median (interquartile } \\
\text { the number of missing }\end{array}$ \\
\hline
\end{tabular}

participants (84.6\%) took part in the study. Of these persons, 32 indicated that they do not perform colposcopies and were therefore excluded. Ultimately, the questionnaires from 160 participants were taken into account in the assessment. - Fig. 1 summarises the course of the study schematically.

\section{Study population}

- Table 1 shows the study population. 75.2\% of the persons surveyed annually treated more than 50 women with genital dysplasia $(22.3 \%$ between 50 and 100 women, $52.9 \%$ more than 100 women annually). In addition, the vast majority of the participants (72.3\%) had obtained at least a colposcopy certificate or had additionally passed a personalised certification according to the concept of the German Society of Colposcopy and Cervical Pathology (AG-CPC).

- Tables $\mathbf{2}$ to $\mathbf{4}$ show the results from the responses to the questions regarding patient information prior to the colposcopic examination, performing the colposcopic examination and the associated documentation as well as performing the conisation.

\section{Providing information to patients}

93.1\% of the persons surveyed indicated that they provide detailed information on the significance of genital dysplasia directly 
- Table 3 Examination procedure and documentation.

\begin{tabular}{|c|c|}
\hline Parameter & Value \\
\hline Type of colposcope* & {$[2]$} \\
\hline - binocular colposcope & $96(60.8 \%)$ \\
\hline - video colposcope & $79(50.0 \%)$ \\
\hline Live video for patients (yes/no) & $124(78.0) / 35(22.0 \%)[1]$ \\
\hline Cervical biopsies performed (yes/no) & $149(94.3 \%) / 9(5.7 \%)[2]$ \\
\hline \multicolumn{2}{|l|}{ If yes... } \\
\hline $\begin{array}{l}\text { - estimated percentage of cases } \\
\text { in which biopsies are taken (\%) }\end{array}$ & $70(30-90)[9]$ \\
\hline - average number of biopsies taken & [2] \\
\hline-1 biopsy & $34(23.1 \%)$ \\
\hline - 2 biopsies & $99(67.3 \%)$ \\
\hline - 3 biopsies & $12(8.2 \%)$ \\
\hline - 4 or more biopsies & $2(1.4 \%)$ \\
\hline - Local anaesthesia given (yes/no) & $8(5.5 \%) / 138(94.5 \%)[3]$ \\
\hline - Using infiltration & $5(62.5 \%)$ \\
\hline - Using spray anaesthetic & $3(37.5 \%)$ \\
\hline $\begin{array}{l}\text { - Use of other/additional methods } \\
\text { for pain relief: }{ }^{*}\end{array}$ & {$[1]$} \\
\hline - No other/additional methods & $71(48.0 \%)$ \\
\hline - Have patient cough & $72(48.6 \%)$ \\
\hline - Distraction through conversation & $4(2.7 \%)$ \\
\hline - Local anaesthesia if necessary & $4(2.7 \%)$ \\
\hline $\begin{array}{l}\text { - Haemostatic measures (in non- } \\
\text { pregnant/pregnant patients) }\end{array}$ & {$[1] /[4]$} \\
\hline - compression with a swab & $81(54.7 \%) / 86(59.3 \%)$ \\
\hline - silver nitrate stick & $60(40.5 \%) / 35(24.1 \%)$ \\
\hline - Monsel's solution & $55(37.2 \%) / 43(29.7 \%)$ \\
\hline - tamponade & $44(29.7 \%) / 50(34.5 \%)$ \\
\hline - policresulen & $30(20.3 \%) / 7(4.8 \%)$ \\
\hline $\begin{array}{l}\text { - tamponade with Monsel's } \\
\text { solution }\end{array}$ & $7(4.7 \%) / 8(5.5 \%)$ \\
\hline - electrocoagulation & $5(3.4 \%) / 5(3.4 \%)$ \\
\hline - resorbable cellulose & $4(2.7 \%) / 1(0.7 \%)$ \\
\hline - suture & $1(0.7 \%) / 2(1.4 \%)$ \\
\hline - tranexamic acid & $1(0.7 \%) / 1(0.7 \%)$ \\
\hline $\begin{array}{l}\text { - no use of haemostatic measures } \\
\text { as standard procedure }\end{array}$ & $9(6.1 \%) / 9(6.2 \%)$ \\
\hline lodine specimen performed (yes/no) & $60(38.0 \%) / 98(62.0 \%)[2]$ \\
\hline There is documentation of the ... & [3] \\
\hline $\begin{array}{l}\text { " Feasibility (“adequate”, } \\
\text { "inadequate") (yes/no) }\end{array}$ & $148(94.3 \%) / 9(5.7 \%)$ \\
\hline $\begin{array}{l}\text { - Squamous epithelium/columnar } \\
\text { epithelium border (yes/no) }\end{array}$ & $142(90.4 \%) / 15(9.6 \%)$ \\
\hline - Transformation zone (yes/no) & $154(98.1 \%) / 3(1.9 \%)$ \\
\hline $\begin{array}{l}\text { Values are numbers (proportion in perc } \\
\text { range). Numbers in square brackets ind } \\
\text { values. }{ }^{*} \text { Multiple selections possible (ar }\end{array}$ & $\begin{array}{l}\text { or median (interquartile } \\
\text { the number of missing } \\
\text { nts may yield > 100\%). }\end{array}$ \\
\hline
\end{tabular}

- Table 4 Conisation (performed by $\mathrm{n}=136$ study participants).

\begin{tabular}{|c|c|}
\hline Parameter & Value \\
\hline \multicolumn{2}{|l|}{ Conisation technique* } \\
\hline - loop electrosurgical conisation & $124(91.2 \%)$ \\
\hline - laser conisation & $40(29.4 \%)$ \\
\hline - knife conisation & $10(7.4 \%)$ \\
\hline - straight wire conisation & $10(7.4 \%)$ \\
\hline \multicolumn{2}{|l|}{ Haemostatic measures* } \\
\hline - electrical (spray coagulation mode) & $87(64.0 \%)$ \\
\hline - electrical (forced coagulation mode) & $62(45.6 \%)$ \\
\hline - Monsel's solution & $12(8.8 \%)$ \\
\hline - laser or thermal coagulation & $10(7.4 \%)$ \\
\hline $\begin{array}{l}\text { - specific interrupted suture or suture } \\
\text { ligation }\end{array}$ & $9(6.6 \%)$ \\
\hline - resorbable cellulose & $4(2.9 \%)$ \\
\hline - silver nitrate stick & $3(2.2 \%)$ \\
\hline - policresulen & $3(2.2 \%)$ \\
\hline - Sturmdorf suture & $3(2.2 \%)$ \\
\hline $\begin{array}{l}\text { no measure in the case of minor } \\
\text { bleeding }\end{array}$ & $30(22.1 \%)$ \\
\hline $\begin{array}{l}\text { Standard prevention of secondary } \\
\text { bleeding* }\end{array}$ & [2] \\
\hline - none & $98(73.1 \%)$ \\
\hline - tamponade & $34(25.4 \%)$ \\
\hline - tamponade with Monsel's solution & $3(2.2 \%)$ \\
\hline - Monsel's solution & $3(2.2 \%)$ \\
\hline Anaesthesia & [16] \\
\hline - general anaesthesia & $111(92.5 \%)$ \\
\hline - paracervical block & $5(4.2 \%)$ \\
\hline - spinal anaesthesia & $2(1.7 \%)$ \\
\hline - intracervical injection & $2(1.7 \%)$ \\
\hline Colposcopy prior to conisation & [2] \\
\hline - never & $2(1.5 \%)$ \\
\hline - in less than $50 \%$ of cases & $7(5.2 \%)$ \\
\hline - in more than $50 \%$ of cases & $1(0.7 \%)$ \\
\hline - in $95 \%$ or more of cases & $22(16.4 \%)$ \\
\hline - always & $102(76.1 \%)$ \\
\hline $\begin{array}{l}\text { Conisation under colposcopic } \\
\text { visualisation (yes/no) }\end{array}$ & $82(61.2 \%) / 52(38.8 \%)[2]$ \\
\hline $\begin{array}{l}\text { Values are numbers (proportion in perce } \\
\text { range). Numbers in square brackets indi } \\
\text { values. }{ }^{*} \text { Multiple selections possible (am }\end{array}$ & $\begin{array}{l}\text { or median (interquartile } \\
\text { the number of missing } \\
\text { nts may yield > 100\%). }\end{array}$ \\
\hline
\end{tabular}


- Table 5 Univariate analysis of the most important parameters.

\begin{tabular}{|c|c|c|c|c|c|c|}
\hline & Group: & & & & & \\
\hline Parameter & Age & Sex & Training & $\begin{array}{l}\text { Years of } \\
\text { practice }\end{array}$ & $\begin{array}{l}\text { Number of } \\
\text { treatments, } \\
\text { total }\end{array}$ & $\begin{array}{l}\text { Number of } \\
\text { treatments } \\
\text { annually }\end{array}$ \\
\hline Number of biopsies in the case of colposcopy & 0.288 & 0.098 & 0.945 & 0.970 & 0.906 & 0.326 \\
\hline Local anaesthesia for biopsy & 0.967 & 0.009 & 0.908 & 0.492 & 0.620 & 0.017 \\
\hline \multicolumn{7}{|l|}{ Conisation technique } \\
\hline - laser & 0.189 & 0.553 & 0.812 & 0.956 & 0.975 & 0.613 \\
\hline " knife & 0.855 & 0.662 & 0.752 & 0.471 & 0.757 & 0.033 \\
\hline - loop electrosurgical & 0.353 & 0.187 & 0.284 & 0.275 & 0.306 & 0.024 \\
\hline - straight wire electrosurgical & 0.377 & 0.112 & 0.752 & 0.206 & 0.975 & 0.613 \\
\hline \multicolumn{7}{|l|}{ Prevention of secondary bleeding after conisation } \\
\hline - tamponade & 0.906 & 0.186 & 0.568 & 0.102 & 0.532 & 0.810 \\
\hline - no measure & 0.810 & 0.217 & 0.818 & 0.383 & 0.395 & 0.355 \\
\hline Conisation under colposcopic visualisation & 0.574 & 0.599 & 0.981 & 0.039 & 0.092 & 0.358 \\
\hline
\end{tabular}

before the colposcopic examination which is also primarily performed by the doctor him-/herself (98.6\%). However, by comparison, only $36.5 \%$ use the option of providing information with the aid of information brochures or videos. Only $9.6 \%$ of those surveyed obtain written consent for the colposcopic examination along with biopsy excision. Written information regarding steps to take following the colposcopy/biopsy in the form of a flyer is handed out by only $11.5 \%$. At the same time, the majority (77.8\%) offers an option for contact in the event of emergencies following the examination. Likewise, the majority of persons surveyed $(78.0 \%)$ offer their patients the opportunity to follow the examination on a monitor ("live video colposcopy").

\section{Univariate analysis of the most important parameters}

- Table 5 shows a univariate analysis of the most important parameters based on the implementation of the colposcopy and conisation. The study participants take an average of two specimens (67.3\% of all persons surveyed). Only $8.2 \%$ of those surveyed preferred to take an average of three specimens. Female and male study participants take an equivalent number of cervical biopsies (2 [1-2] vs. 2 [2-2]; $p=0.09)$. Female participants (1.1 vs. $12.7 \%, p=0.009)$ and participants who examine more than 50 patient cases annually during their consultations ( $<3$ vs. $15.6 \% ; p=0.01$ ) tended not to perform local anaesthesia prior to taking biopsies. Based on the conisation technique, it can be concluded that study participants who annually treat > 100 women to clarify dysplasia in their consultations perform conisation with the knife more rarely ( 2.5 vs. $14.3 \%$; $p=0.03$ ) and prefer the loop excision ( 96.3 vs. $83.9 \%$; $=0.02$ ). Moreover, it can be noted that study participants with more colposcopy experience also perform conisation under colposcopic visualisation far more frequently (71.7 vs. $52.7 \%$; $p=0.039$ ). Regarding the question of method of anaesthesia during conisation, the result is clear: $92.5 \%$ of all of those surveyed perform conisation under general anaesthesia.
Nearly three quarters of those surveyed (73.1\%) do not use any preventive measures to avoid secondary bleeding, while $27.6 \%$ insert a tamponade with or without Monsel's solution intravaginally.

\section{Discussion}

The early detection of cervical carcinoma is facing a radical change in Germany - from an opportunistic to an organised screening. Current discussions primarily address the management of cervical dysplasia and the optimal algorithm for clarification. Against the background of the expected significant increase in the use of colposcopies in dysplasia consultations and facilities, the focus must also turn to the optimal treatment of affected women within the scope of colposcopic clarification. To this end, this work describes the current management of gynaecologists who perform colposcopies in German-speaking countries. The data from this study are intended to serve as a basis for further efforts to improve the quality of treatment of women with cervical dysplasia.

A response rate of approx. $23 \%$ in our study coincides with the response rates from other web-based surveys aimed at Germanspeaking gynaecologists [11]. Slightly over three quarters of the participants in our study regularly treated patients with genital dysplasia, that is, more than 50 cases per year; this figure was even more than 100 cases annually for more than half of the participants. In addition, the vast majority of the participants had acquired at least the colposcopy certificate or additionally obtained a personalised certification according to the concept of the Working Group for Colposcopy and Cervical Pathology (AG-CPC). This collective is thus a representative cross-section of those clinicians who will have a decisive influence on the future quality of care of affected women.

More than 9 out of 10 persons surveyed indicated that they provide detailed patient information on the significance of genital 
dysplasia directly before the colposcopic examination, nearly always by the physician him-/herself. However, only about one third utilise the option of providing information with the aid of information brochures or videos. Additional information using information brochures and/or videos does not, in fact, reduce women's anxiety [12 - 14], but randomised studies have been able to demonstrate a positive effect of knowledge about the disease [15] and a lower risk for the development of psychosexual problems [14].

Fewer than $10 \%$ of study participants indicated that they obtain written consent for the colposcopic examination plus biopsy excision. The biopsy at the uterine cervix does not, in fact, represent a risky procedure with regard to the risk of a serious organic complication; nonetheless it is advisable to obtain written consent along with documentation of the patient information for forensic reasons, since the occurrence of severe pain and discomfort during the examination and, in particular, long-term psychological damage to the point of depression have been described in the literature [16-19]. In this respect, written information regarding measures to take following the colposcopy or biopsy in the form of a flyer could also be very helpful for women. However, this is done by just over $10 \%$ of all physicians in this collective. At the same time, however, at least more than three out of four physicians offer a possibility for contact in the event of emergencies after the examination.

Nearly $80 \%$ of those surveyed offer their patients the option to follow the examination on a monitor ("live video colposcopy"). In one randomised study, following their own examination had no effect on patients' anxiety [20]. At the same time in the same study, however, the importance of the live video colposcopy for the understanding of the clinical picture was assessed as very high, with a median point score of 9 out of 10 possible points. Therefore the use of live video colposcopy can be readily recommended.

Colposcopy with targeted biopsy is the gold standard procedure to detect cervical precancerous cells in women with at least one positive investigative test (PAP and/or HPV test) [4]. The number of biopsies to be taken at the uterine cervix is a frequently discussed topic in this connection. A small number of participants in this survey (5.9\%) indicated that they do not perform a biopsy as a standard measure. Further analysis of this subgroup was not able to be done since we did not ask about the indication for performing the colposcopy (screening result) or the findings determined during the colposcopy (e.g. visibility of the transformation zone or "minor" vs. "major" change). However, it should be noted that a biopsy should always be performed for "minor" and "major" changes in order to guarantee a high level of reliability of the colposcopy [21]. By contrast, about two thirds of the participants in our study indicated that they take an average of two specimens; only about $8 \%$ indicated that they prefer taking an average of three specimens. This corresponds to the current evidence from international studies according to which the sensitivity of the detection of CIN2+ lesions is a maximum of $93.2 \%$ when two biopsies are taken and, if an additional third biopsy is taken, this increases only slightly to $95.6 \%[22,23]$.

Another important question during the colposcopic examination is whether local anaesthesia prior to cervical biopsy is necessary. In our collective, the answer to this is clearly "no" (94.5\%). In a randomised work, Schmid et al. were able to demonstrate that a strong cough during the biopsy is just as effective as local anaesthesia with lidocaine, however at the same time, it significantly reduces the examination time [24]. Nearly half of those surveyed in our study also asked their patients to cough during the biopsy, whereas nearly the other half does not consider any measures.

The most frequent haemostatic measures after biopsy at the uterine cervix in pregnant as well as non-pregnant patients are quoted as, in descending order, compression of the biopsy site using swabs, the use of silver nitrate sticks or Monsel's solution and the vaginal insertion of a tamponade. Only a small minority (6.1\%) uses no haemostatic measures as a standard approach. The only randomised work available on this topic was able to demonstrate that the use of Monsel's solution in comparison to no measure leads to a significant reduction in the severity of the bleeding only within the first 6 hours after cervical biopsy, yet at the same time, it has no influence on patients' pain perception or satisfaction [25]. Thus the use of a haemostatically effective measure could be limited to women who bleed very heavily following a cervical biopsy.

Conisation was previously considered to be the standard method for the surgical treatment of cervical intraepithelial neoplasias and defines the removal of a cone of tissue together with dysplastic lesions from the uterine cervix [26]. To avoid considerable perinatal and oncological long-term complications (premature birth and recurrence of dysplasia), the conisation must be performed with as little tissue damage as possible, yet with a high degree of oncological reliability at the same time $[27,28]$. The electrosurgical loop excision in the form of a large loop excision of the transformation zone (LLETZ) represents the most frequently used surgical method due to the fact that it is easy to perform, quick to learn, and offers a low rate of complications [29]. This was also reflected in this collective in which more than 9 out of 10 persons surveyed primarily use loop conisation with the electrosurgical loop. In this procedure, the entire transformation zone is resected using a circular electrosurgical loop [30]. The preference for this loop also correlates with the number of women with cervical dysplasia examined annually. These data also correspond to the current literature, according to which loop excision is superior to other methods with regard to the long-term complications listed and knife conisation is considered obsolete [31-34]. A recently published and, to date, the only randomised work on the topic "conisation under colposcopic visualisation" additionally comes to the conclusion that conisation performed under colposcopic visualisation leads to the removal of cones with a smaller volume without influencing the resection status [35]. In the present collective, this procedure is used by about two thirds of surgeons, whereby those with more colposcopy experience perform conisation far more frequently under colposcopic visualisation.

The results listed here cannot, however, be used equally for the surgical treatment of all women. In our study, we limited ourselves to the evaluation of excision methods and did not additionally inquire into ablative methods such as laser ablation and cryotherapy. In particular, laser ablation represents an alternative treatment method and is equivalent to LLETZ [31]. The local excision of a colposcopically visible lesion without removal of the entire transformation zone also increasingly plays a larger role in clinical practice. To date, however, there are no randomised stud- 
ies available for this type of surgical intervention which were able to demonstrate the equivalence of the local excision at the cervix compared to the complete removal of the transformation zone. A planned phase III study in Germany regarding this issue is still currently recruiting [36].

More than $90 \%$ of those surveyed indicated that they perform conisation under general anaesthesia, which is surprising in view of the fact that there is no evidence for the preference of general anaesthesia in comparison to local methods. In Great Britain and North America, by contrast, conisation is performed almost exclusively under local anaesthesia. A current, prospective, randomised study from our working group intends to answer this question in the future (https://clinicaltrials.gov, protocol number NCT03494686).

After removal of the cone specimen, electric coagulation of the wound area is by far the most frequently used haemostatic measure. In another work by our study group, both haemostatic options ("spray" versus "forced" mode) were compared in this regard under randomised conditions. We were able to demonstrate that the spray mode leads to significantly faster haemostasis [37]. The participants in the present questionnaire-based study also indicated that they preferred to use this method. With regard to the question of avoiding secondary bleeding after conisation, nearly three quarters of those surveyed indicated that they do not use any preventive measures, whereas the remaining quarter places a tamponade with or without Monsel's solution intravaginally. No evidence is available for the latter method and should not be performed in the authors' view either.

\section{Conclusion for Clinical Practice}

The majority of colposcopy specialists take an average of two cervical biopsies (67.3\%) and during this procedure, nearly all persons surveyed (94.5\%) do not perform any local anaesthesia. The most frequently used method by colposcopy experts in Germany to remove precancerous cervical cells is loop excision with the electrosurgical loop (91.2\%) under colposcopic visualisation (61.2\%) under general anaesthesia (92.5\%). A uniform procedure should be defined in detail within the scope of directives or guidelines.

\section{Conflict of Interest}

The authors declare that they have no conflict of interest.

\section{References}

[1] Ferlay J, Soerjomataram I, Dikshit R et al. Cancer incidence and mortality worldwide: sources, methods and major patterns in GLOBOCAN 2012. Int J Cancer 2015; 136: E359-E386

[2] Robert Koch-Institut. Krebs in Deutschland 2013/2014. 11. Ausgabe. Berlin: RKI; 2017

[3] Gemeinsamer Bundesausschuss. Pressemitteilung 39. Früherkennung von Gebärmutterhalskrebs künftig als organisiertes Programm. 2018. Online: https://www.g-ba.de/downloads/34-215-774/39_2018-11-22_ oKFE_Zervix.pdf; last access: 23.11.2018
[4] Leitlinienprogramm Onkologie. S3-Leitlinie Prävention des Zervixkarzinoms. 2017. Online: https://www.leitlinienprogrammonkologie.de/ fileadmin/user_upload/Downloads/Leitlinien/Zervixkarzinom_ Praeventin/LL_Pr\%c3\%a4vention_des_Zervixkarzinoms_Langversion_ 1.0.pdf; last access: 24.07 .2018

[5] Moss EL, Arbyn M, Dollery E et al. European Federation of Colposcopy quality standards Delphi consultation. Eur J Obstet Gynecol Reprod Biol 2013; 170: 255-258

[6] Beckmann MW, Quaas J, Bischofberger A et al. Aufbau des Zertifizierungssystems "Gynäkologische Dysplasie“ in Deutschland. Geburtsh Frauenheilk 2014; 74: 860-867

[7] Wentzensen N, Massad LS, Mayeaux EJ et al. Evidence-Based Consensus Recommendations for Colposcopy Practice for Cervical Cancer Prevention in the United States. J Low Genit Tract Dis 2017; 21: 216-222

[8] Waxman AG, Conageski C, Silver MI et al. ASCCP Colposcopy Standards: How Do We Perform Colposcopy? Implications for Establishing Standards. J Low Genit Tract Dis 2017; 21: 235-241

[9] NHS Cervical Screening Programme. Colposcopy and Programme Management. Third Edition. 2016. Online: https://www.bsccp.org.uk/assets/ file/uploads/resources/NHSCSP_20_Colposopy_and_Programme_ Management_(3rd_Edition)_(2).pdf; last access: 26.07.2018

[10] Harris PA, Taylor R, Thielke R et al. Research electronic data capture (REDCap) - A metadata-driven methodology and workflow process for providing translational research informatics support. J Biomed Inform 2009; 42: 377-381

[11] Hancke K, Igl W, Toth B et al. Work-life balance of German gynecologists: a web-based survey on satisfaction with work and private life. Arch Gynecol Obstet 2014; 289: 123-129

[12] Byrom J, Clarke T, Neale J et al. Can pre-colposcopy sessions reduce anxiety at the time of colposcopy? A prospective randomised study. J Obstet Gynaecol 2002; 22: 415-420

[13] Chan YM, Lee PH, Ng TY et al. Could precolposcopy information and counseling reduce women's anxiety and improve knowledge and compliance to follow-up? Gynecol Oncol 2004; 95: 341-346

[14] Howells RE, Dunn PD, Isasi T et al. Is the provision of information leaflets before colposcopy beneficial? A prospective randomised study. BJOC 1999; 106: 528-534

[15] Marteau TM, Kidd J, Cuddeford L. Reducing anxiety in women referred for colposcopy using an information leaflet. British Journal of Health Psychology 1996; 1: 181-189

[16] Kavanagh AM, Broom DH. Women's understanding of abnormal smear test results: a quantitative interview study. BMJ 1997; 314: 1388-1391

[17] Kola S, Walsh JC. Determinants of pre-procedural state anxiety and negative affect in first-time colposcopy patients: implications for intervention. Eur J Cancer Care 2012; 21: 469-476

[18] Rogstad KE. The psychological impact of abnormal cytology and colposcopy. BJOG 2002; 109: 364-368

[19] Sharp L, Cotton S, Little J et al. Psychosocial impact of alternative management policies for low-grade cervical abnormalities: results from the TOMBOLA randomised controlled trial. PLoS One 2013; 8: e80092

[20] Hilal Z, Alici F, Tempfer CB et al. Video Colposcopy for Reducing Patient Anxiety During Colposcopy: A Randomized Controlled Trial. Obstet Gynecol 2017; 130: 411-419

[21] Petry KU, Luyten A, Scherbring S. Accuracy of colposcopy management to detect CIN3 and invasive cancer in women with abnormal screening tests: results from a primary HPV screening project from 2006 to 2011 in Wolfsburg, Germany. Gynecol Oncol 2013; 128: 282-287

[22] Van der Marel J, van Baars R, Rodriguez A et al. The increased detection of cervical intraepithelial neoplasia when using a second biopsy at colposcopy. Gynecol Oncol 2014; 135: 201-207

[23] Wentzensen N, Walker JL, Gold MA et al. Multiple biopsies and detection of cervical cancer precursors at colposcopy. J Clin Oncol 2015; 33: 83-89 
[24] Schmid BC, Pils S, Heinze G et al. Forced coughing versus local anesthesia and pain associated with cervical biopsy: a randomized trial. Am J Obstet Gynecol 2008; 199: 641-643

[25] Hilal Z, Rezniczek GA, Tettenborn Z et al. Efficacy of Monsel Solution After Cervical Biopsy: A Randomized Trial. J Low Genit Tract Dis 2016; 20: $312-316$

[26] Massad LS, Einstein MH, Huh WK et al. 2012 ASCCP Consensus Guidelines Conference. 2012 updated consensus guidelines for the management of abnormal cervical cancer screening tests and cancer precursors. Obstet Gynecol 2013; 21: 829-846

[27] Ghaem-Maghami S, Sagi S, Majeed G et al. Incomplete excision of cervical intraepithelial neoplasia and risk of treatment failure: a meta-analysis. Lancet Oncol 2007; 8: 985-993

[28] Kyrgiou M, Athanasiou A, Paraskevaidi M et al. Adverse obstetric outcomes after local treatment for cervical preinvasive and early invasive disease according to cone depth: systematic review and meta-analysis. BMJ 2016; 354: 3633

[29] Stasinou SM, Valasoulis G, Kyrgiou M et al. Large loop excision of the transformation zone and cervical intraepithelial neoplasia: a 22-year experience. Anticancer Res 2012; 32: 4141-4145

[30] Bornstein J, Bentley J, Bösze P et al. 2011 colposcopic terminology of the International Federation for Cervical Pathology and Colposcopy. Obstet Gynecol 2012; 120: 166-172
[31] Martin-Hirsch PP, Paraskevaidis E, Bryant A et al. Surgery for cervical intraepithelial neoplasia. Cochrane Database Syst Rev 2013; (12): 1318

[32] Hilal Z, Rezniczek GA, El-Fizazi N et al. Large Loop Excision of the Transformation Zone Versus True Cone Biopsy Electrode Excision: A Randomized Trial. J Low Genit Tract Dis 2017; 21: 272-278

[33] Jiang YM, Chen CX, Li L. Meta-analysis of cold-knife conization versus loop electrosurgical excision procedure for cervical intraepithelial neoplasia. Onco Targets Ther 2016; 9: 3907-3915

[34] Arbyn M, Kyrgiou M, Simoens C et al. Perinatal mortality and other severe adverse pregnancy outcomes associated with treatment of cervical intraepithelial neoplasia: meta-analysis. BMJ 2018; 337: a1284

[35] Hilal Z, Rezniczek GA, Alici F et al. Loop Electrosurgical Excision Procedure (LEEP) with or without Intraoperative Colposcopy: A Randomized Trial. Am J Obstet Gynecol 2018. doi:10.1016/j.ajog.2018.07.023

[36] Schwarz TM, Kolben T, Gallwas ] et al. Comparison of two surgical methods for the treatment of CIN: classical LLETZ (large-loop excision of the transformation zone) versus isolated resection of the colposcopic apparent lesion - study protocol for a randomized controlled trial. Trials 2015; 16: 225

[37] Hilal Z, Mavrommati G, Foerster C et al. Spray Versus Forced Coagulation in Large Loop Excision of the Transformation Zone: A Randomized Trial. J Low Genit Tract Dis 2016; 20: 169-173 